\title{
Last resort antibiotherapy in sepsis with MDR bacteria, one possible solution in a critical patient (case report)
}

Doina lovănescu*, Cătălin Apostolescu, Cleo Roşculeț, Monica Ivan, Alina Frangulea, Monica Ungureanu, Ana-Maria Petrescu, Bogdana Manu, Cornel Camburu, Andrei Rogoz, Aida Răşcanu, Marius Radu

From The 9th Edition of the Scientific Days of the National Institute for Infectious Diseases Prof Dr Matei Bals Bucharest, Romania. 23-25 October 2013

\section{Background}

The purpose of this case report was to present the extreme difficulties in finding a solution for the patient with sepsis treatment determined by bacteria associations: MRSA, ESBL $K$ pneumoniae, E coli with ESBL.

\section{Case report}

We present the case report of a 68-year old male patient, with a history of prostate cancer surgery, relapsed and irradiated. Microbiological and antibiogram data, and the parameters of organ dysfunction represented the basis for an "extreme" decision in the antibiotherapy scheme. We obtained microbiological control and we successfully managed the vital dysfunctions.

\section{Conclusion}

Desperate situations sometimes require last resort decisions, extremely costly which can save the patient for the moment; the question we ask ourselves is whether this control is also supported and for how long.

Submit your next manuscript to BioMed Central and take full advantage of:

- Convenient online submission

- Thorough peer review

- No space constraints or color figure charges

- Immediate publication on acceptance

- Inclusion in PubMed, CAS, Scopus and Google Scholar

- Research which is freely available for redistribution \\ () Biomed Central}

